\title{
A 64-year study of a Pied Flycatcher Ficedula hypoleuca population
}

\author{
En 64 år lång studie av en svartvit flugsnapparpopulation
}

KARL GUSTAV SCHÖLIN \& HANS KÄLLANDER

\begin{abstract}
A nestbox breeding population of Pied Flycatchers Ficedula hypoleuca was monitored during 64 years in a mixed coniferous-deciduous forest area near Örebro, South Central Sweden. The population showed a continuous average decline of c. 0.5 pairs per year, from c. $50 \%$ to c. $20 \%$ occupancy. There was a strong negative correlation between flycatcher numbers and those of other hole-nesters, but it is doubtful whether any causal relationship existed. Mean laying date was 24 May (17 May-3 June) and showed a negative correlation with mean May temperatures, yet no significant trend over the six decades. Mean laying date did, however, show an increased variation during the last 20 years. Mean clutch

size varied between 5.76 and 7.08, with a mean of 6.34 . It varied more during the last 30 years but without any significant relationship with mean laying date. A mean of 5.96 young fledged from broods that produced at least one fledgling vs 5.34 for all broods; the lower figure was mainly a consequence of nest predation by Pine Marten Martes martes, particularly after the early 1980 s.

Karl-Gustav Schölin, Kyrkvärdsgatan 10, SE-702 84 Örebro,Sweden,E-mail: kalle.scholin@gmail.com Hans Källander, Department of Biology, Lund University, Ecology Building, SE-223 62 Lund, Sweden. E-mail: hans.kallander@telia.com
\end{abstract}

Received 24 March 2011, Accepted 18 October 2011, Editor: J. Waldenström

\section{Introduction}

Because Pied Flycatchers Ficedula hypoleuca readily accept nestboxes and are relative insensitive to disturbance, two conditions that make them easy to study, it is hardly surprising that there exists an enormous literature on the species. By far the largest number of studies deal with aspects of its breeding biology, and data on basic breeding parameters, such as start of egg laying, clutch size and fledging success, are available from practically all parts of the species' distribution range, including several places in Sweden. Much of this information has been presented in a monograph by Lundberg \& Alatalo (1992). Their reference list, together with that of Winkel (1993), gives a good illustration of the amount of published information that exists on the Pied Flycatcher.

Here we report results from a long-term study of Pied Flycatchers initiated in 1948 and which is still on-going. We investigate long-term trends in breeding numbers and reproductive performance and analyse whether they may be correlated with spring temperatures and number of other holenesting species.

\section{Study area and methods}

The study was started by the first author when he put up 80 nestboxes prior to the 1948 breeding season, and who has since carried out all field work and data collection. A description of the study area SE of Örebro in South Central Sweden $\left(59^{\circ} 14^{\prime} \mathrm{N}, 15^{\circ} 13^{\prime} \mathrm{E}\right)$ is given in Schölin (2009). The area consists predominantly of mixed coniferous-deciduous forest, interspersed with small, nowadays often abandoned and partly overgrown fields. The latter process has led to an increase in the proportion of deciduous trees, especially birch Betula sp. and aspen Populus tremula, during the last 30 years. The nestboxes were placed at a height of c. $2.5 \mathrm{~m}$ with some 40 to $50 \mathrm{~m}$ between them along a winding path within a $0.5 \times 1 \mathrm{~km}$ area of forest. Many boxes were placed in forest clearings and at forest edges. The majority were normal wooden boxes, but about a third consisted of hollowed-out tree trunks. The mean base area of the boxes was c. $112 \mathrm{~cm}^{2}$, the entrance holes had a mean diameter of $30 \mathrm{~mm}$ and the distance from the lower rim of the entrance hole to the box base was on average $16 \mathrm{~cm}$. The boxes, which had no 


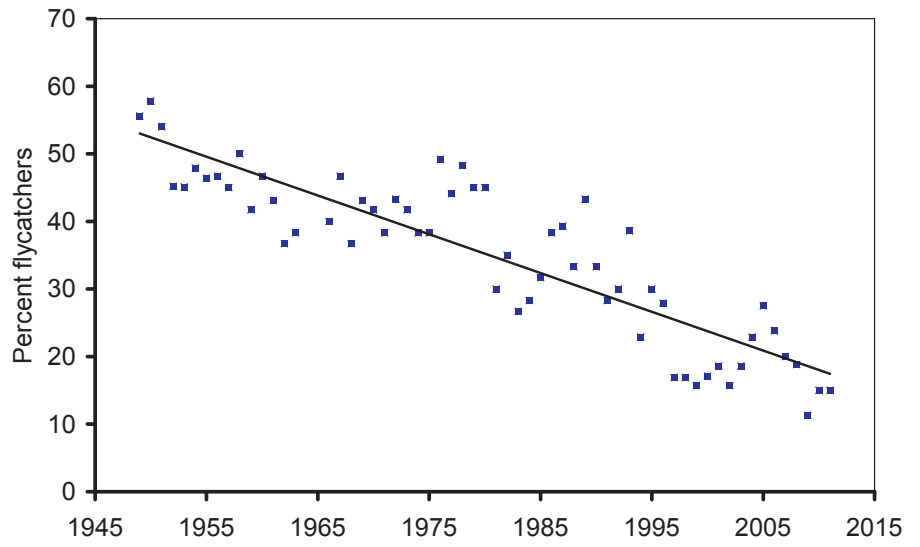

Figure 1. The negative population trend of Pied Flycatchers at Lövsätter, South Central Sweden, during 1949-2010 (1948 excluded because it was the first year with nestboxes).

Den negativa trenden för svartvit flugsnapparpopulationen vid Lövsätter 1949-2010 (1948 har uteslutits eftersom holkbeståndet var nyetablerat detta år). $Y$-axeln visar procenten flugsnappare. anti-predator devices, were replaced successively as needed.

The nestboxes, which varied in number over the period, were checked about once a week to record clutch initiation, clutch size, nest success, etc. Sometimes inspection intervals were slightly longer (up to 10 days), which means that in some cases the laying date for a few clutches could not be determined with desirable precision. Those nests were excluded from analyses involving laying date. Sixteen clutches started in late June or early July, i.e. three weeks or more after the normal laying period, were excluded from all analyses (see von Haartman (1989) for the rationale for such exclusion). Likewise, the first year was omitted in analyses of population trends because no or very few Pied Flycatchers were expected to have shown "Ortstreue" in 1948.

Temperature data were taken from the Swedish Meteorological and Hydrological Institute's (SMHI) weather station at Örebro, about $5 \mathrm{~km}$ to the north-west of the study area. Data were analysed by standard statistical methods. In linear regressions with date as the independent variable, 1 May $=1$, and when year is the independent variable, $1949=1$. Linear regressions based on proportions were calculated on arcsin square-root transformed data but are presented as untransformed data. Means are given \pm 1 standard deviation (SD) throughout.

\section{Results}

\section{Population trend and population fluctuations}

In the second year of the study, 1949, about 50\% of the nestboxes were occupied by breeding Pied
Flycatchers. This proportion had fallen to a mere $20 \%$ in 2011, a mean annual decrease corresponding to half a pair per year (Figure 1). Despite some numerical fluctuations during this long period, the decrease is highly statistically significant ( $\mathrm{Y}$ $=-0.574 \mathrm{X}+53.581$, df $=61, \mathrm{P}<0.001)$. It was weaker during the first half of the study $(b=-0.317$ $\%, \mathrm{P}=0.002)$ than during the latter half $(\mathrm{b}=-0.750$ $\%, \mathrm{P}<0.001)$.

There was a strong negative correlation (Figure $\left.2, \mathrm{r}_{\mathrm{s}}=-0.808, \mathrm{P}<0.001\right)$ between the proportions of nestboxes occupied by Pied Flycatchers and by other hole-nesters, especially Great Tits Parus major and Blue Tits Cyanistes cyaneus. The Great Tit population showed its strongest increase after the mid-1980s, while Blue Tits increased rapidly from about 1980. Even though a percentage of boxes

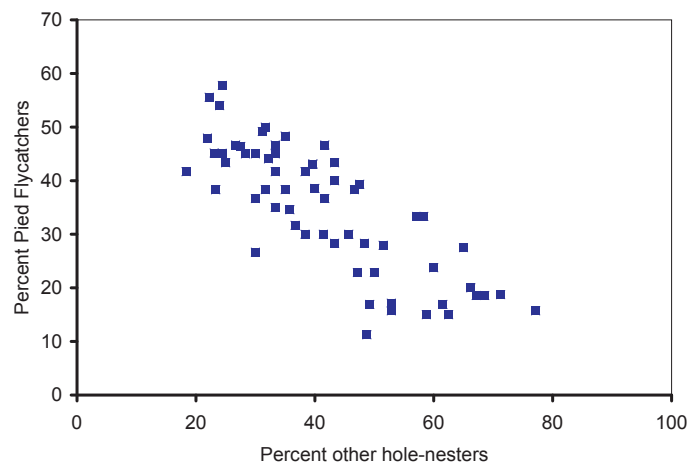

Figure 2. The relationship between percentages of Pied Flycatchers and of other hole-nesters at Lövsätter.

Relationen mellan procenten svartvita flugsnappare Y-axeln) och procenten övriga hålhäckare (X-axeln) vid Lövsätter. 
remained empty in each year (mean 23.4, range 6.7-43.3), the higher proportions of other holenesters may suggest a direct influence on flycatcher numbers. We analysed this by using GLM, with the percentage flycatchers in year $t+1$ as the dependent variable and with the percentage flycatchers in year $t$, their number of fledglings in year $t$ and the percentage of other hole-nesters in year $t+1$ as independent variables. Only the percentages of flycatchers $(\mathrm{P}<0.001)$ and of other hole-nesters $(\mathrm{P}=$ 0.002 ) were statistically significant.

With respect to yearly variations in population size, some studies have found that the production of fledglings in one year affects the number of pairs in the following year. In our study only a weak correlation $(\mathrm{r}=0.267, \mathrm{~N}=60, \mathrm{P}=0.039)$ was found between mean number of fledged young in year $t$ and population change (in \%) to year $t+1$. This correlation was based on nests from which at least one young fledged.

\section{Laying date}

Mean laying date varied during the study period from 17 May in the earliest year (1994) to 3 June in the latest year (1991), with 24 May as the overall mean $(\mathrm{N}=61$ years; Figure 3$)$. May temperatures showed a weak, non-significant trend $(b=0.016$ degrees per year, $\mathrm{P}=0.060$ ) during 1948-2011 (Figure 4) and there was no trend in laying date $(b=$ $0.002, \mathrm{P}=0.919)$. There was, however, a negative

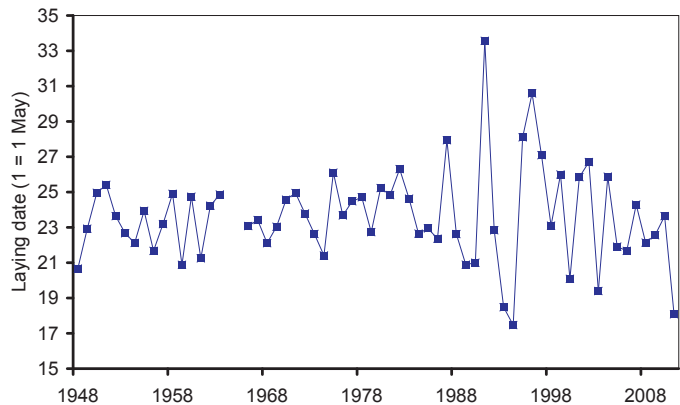

Figure 3. Mean laying date of Pied Flycatchers at Lövsätter during 1948-2011.

Medeldatum för första ägget under vart och ett av åren 1948-2011. Y-axeln visar datum i maj.

trend in mean laying date vs temperature (linear regression, $\mathrm{Y}=-0.807 \mathrm{X}+32.358, \mathrm{R}^{2}=0.138, \mathrm{P}=$ $0.003)$. The relationship between mean May temperature and the season's first egg (Table 1) differed only marginally from these figures $(b=-0.802)$.

To see if other hole-nesters affected the laying time of the Pied Flycatchers, we ran a GLM with mean laying time of the flycatchers as the dependent variable and May temperature and the percentage of other hole-nesters as independent variables. Mean laying date was still negatively related to May temperature $(\mathrm{b}=-0.789, \mathrm{P}=0.004)$, whereas other hole-nesters were not $(b=-0.010, P=0.654)$.

Table 1. The earliest clutch initiation date (May) in each year 1949-2011.

Tidigast lagda ägget $i$ vart och ett av åren 1949-2011.

\begin{tabular}{llllllll}
\hline $\begin{array}{l}\text { Year } \\
\text { Ar }\end{array}$ & $\begin{array}{l}\text { Date } \\
\text { Datum }\end{array}$ & $\begin{array}{l}\text { Year } \\
\text { Ar }\end{array}$ & $\begin{array}{l}\text { Date } \\
\text { Datum }\end{array}$ & $\begin{array}{l}\text { Year } \\
\text { Ar }\end{array}$ & $\begin{array}{l}\text { Date } \\
\text { Datum }\end{array}$ & $\begin{array}{l}\text { Year } \\
\text { Ar }\end{array}$ & $\begin{array}{l}\text { Date } \\
\text { Datum }\end{array}$ \\
\hline 1949 & 17 & 1965 & - & 1981 & 20 & 1997 & 20 \\
1950 & 14 & 1966 & 16 & 1982 & 21 & 1998 & 14 \\
1951 & 17 & 1967 & 16 & 1983 & 20 & 1999 & 22 \\
1952 & 18 & 1968 & 20 & 1984 & 18 & 2000 & 16 \\
1953 & 16 & 1969 & 18 & 1985 & 16 & 2001 & 18 \\
1954 & 19 & 1970 & 21 & 1986 & 16 & 2002 & 18 \\
1955 & 15 & 1971 & 19 & 1987 & 20 & 2003 & 18 \\
1956 & 14 & 1972 & 18 & 1988 & 16 & 2004 & 12 \\
1957 & 16 & 1973 & 17 & 1989 & 20 & 2005 & 14 \\
1958 & 20 & 1974 & 17 & 1990 & 19 & 2006 & 12 \\
1959 & 16 & 1975 & 18 & 1991 & 20 & 2007 & 11 \\
1960 & 20 & 1976 & 18 & 1992 & 16 & 2008 & 12 \\
1961 & 18 & 1977 & 24 & 1993 & 10 & 2009 & 17 \\
1962 & 21 & 1978 & 18 & 1994 & 10 & 2010 & 16 \\
1963 & 19 & 1979 & 16 & 1995 & 23 & 2011 & 15 \\
1964 & - & 1980 & 20 & 1996 & 21 & & \\
\hline
\end{tabular}




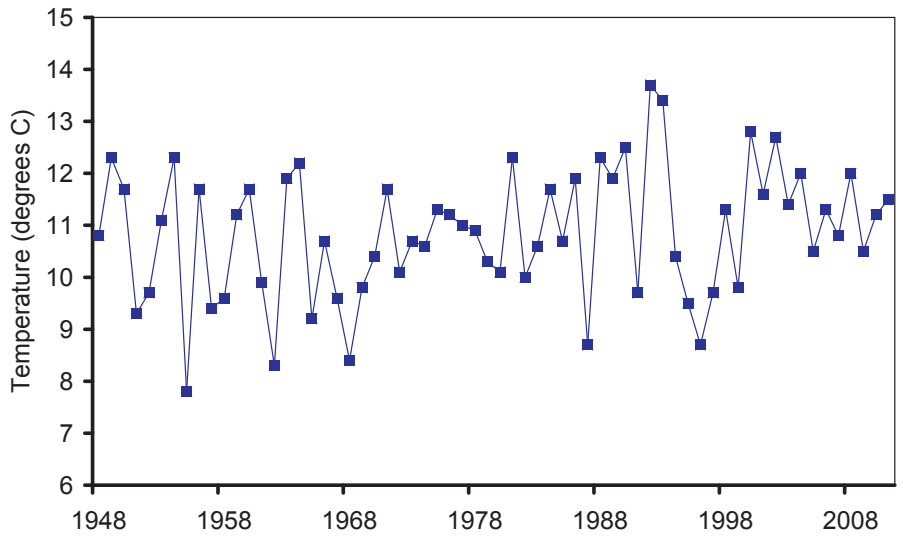

Figure 4. Mean May temperatures during 1948-2011 as recorded at Örebro, c.5 km to the north-west of Lövsätter. Medeltemperaturen (Y-axeln) under åren 1948-2011 för Örebro, c.5 km nordväst om Lövsätter.

\section{Clutch size}

The overall clutch mean for 1948-2011 was 6.34 (Appendix 1), with a modal clutch size of six eggs. The lowest mean clutch size (5.76) was recorded in 1991, the highest (7.08) in 2011. During the first half of the study, mean clutch size remained relatively stable at 6.24 eggs (coefficient of variation, $\mathrm{CV}=2.2 \%$ ), but during the second part it varied considerably more between years $(\mathrm{CV}=4.5 \%$; Figure 5). This was probably an effect of the more variable laying dates during the latter period (cf. Figure 3). Mean clutch size showed a weak but significant negative relationship with population density expressed as percent nestboxes occupied by Pied Flycatchers (Figure 6; linear regression, $\mathrm{Y}=$ $\left.-0.008 \mathrm{X}+6.658, \mathrm{df}=59, \mathrm{R}^{2}=0.147, \mathrm{P}=0.002\right)$. In a GLM with clutch size as the dependent variable and with mean laying date, May temperature, percent other hole-nesters and percent Pied Flycatchers as independent variables, only mean laying date and percent Pied Flycatchers were statistically significant $(\mathrm{P}=0.006$ and $<0.001$, respectively). Within years clutch size generally decreased with laying date. Standardized to median laying date each year, the decrease was $\mathrm{Y}=-0.070 \mathrm{X}+6.471$, $\mathrm{R}^{2}=0.821, \mathrm{P}<0.001$. However, clutches of seven eggs were less common after median laying date during the first half of the study than during the second half ( 38 of 325 clutches vs 74 of $182 ; \chi^{2}=$ 252.1, df $1, \mathrm{P}<0.001)$.

\section{Breeding success}

Including all breeding attempts, the mean number of fledged young was 5.34, slightly lower than for successful pairs (5.96) (Appendix 2). Exclud- ing total clutch and brood losses, the proportion of eggs laid that resulted in fledged young varied relatively little between years, from $78 \%$ to $100 \%$, with a mean of $93 \pm 4.2 \%$. Total losses were, however, relatively common in some years. Out of the 1397 nests in which a clutch was initiated, 133 (9.5\%) failed completely. During 1948-1981, 50 out of 911 clutches failed $(5.5 \%)$ vs 83 out of $486(17.1 \%)$ during 1982-2011. Particularly from 1983 onwards failures were predominantly an effect of predation by Pine Marten Martes martes. During these last 29 years, marten predation occurred during 15 years and caused total loss in 55 nests and partial losses in an additional 13 nests (55 nestlings out of 83; Table 2). Great Spotted Woodpecker Dendrocopos major depredated 15 broods, in 40 boxes all nestlings were found dead, usually shortly after hatching, 12 clutches were deserted, and another 12 nests were found empty but intact.

\section{Discussion}

\section{Population trends and fluctuations}

The studied Pied Flycatcher population decreased, with minor fluctuations, from about 50 pairs during the first years of the study to 12 pairs in 2011. The present study documents that the decrease of the Swedish Pied Flycatcher population may have been going on for some six decades, but unfortunately comparative data series of sufficient duration are lacking for establishing whether this is true or not. Although there was a strong negative correlation between the percentages of flycatchers and of other hole-nesters, it is doubtful whether this indeed constitutes a causal link. Not only was there always empty boxes available but, in particu- 
Figure 5. Mean clutch size of Pied Flycatchers at Lövsätter during 1948-2011.

Medelkullens storlek (Y-axeln) hos svartvit flugsnappare vid Lövsätter de olika åren 1948-2011.

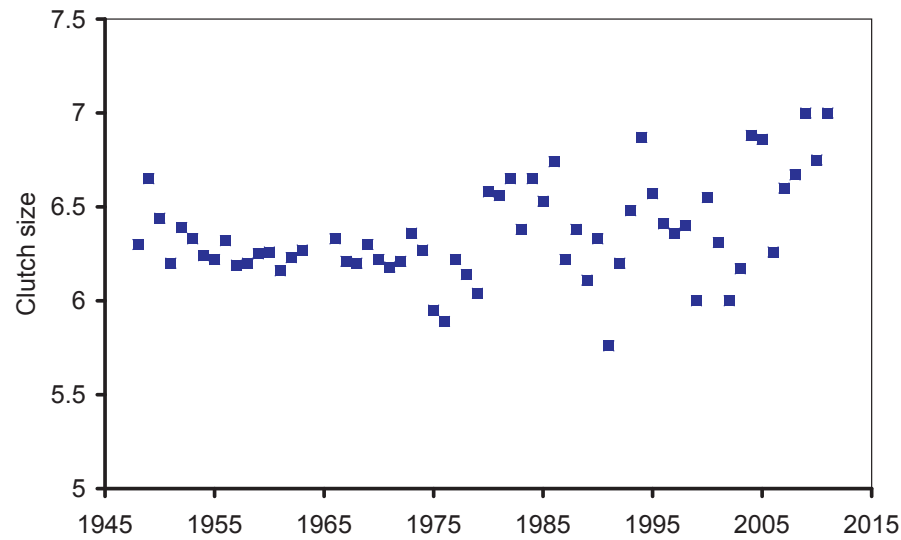

lar, there was no correlation at all between number of empty boxes and Pied Flycatcher numbers ( $\mathrm{r}=$ 0.007).

During the last few decades, a negative trend in Pied Flycatcher population size has been observed in some other Swedish nestbox studies (Sjöberg 2006, E. Nyholm in litt.) as well as in the Swedish Bird Monitoring Programme (Ottvall et al. 2009). The results from nestbox studies in two deciduous woods near Lund $\left(55^{\circ} 44^{\prime} \mathrm{N}, 13^{\circ} 18^{\prime} \mathrm{E}\right)$ also reflect this trend. During the first half of the 1970s the mean number of Pied Flycatcher pairs was 30 and 19, respectively (HK unpubl. data). During 2004-2010, when a large number of nestboxes was again available in these woods, not a single flycatcher pair bred in the boxes (D. Hasselquist pers. comm.). The autumn figures from the standardized



Figure 6. The relationship between Pied Flycatcher mean clutch size and population density (expressed as percent occupied nestboxes), Lövsätter 1948-2010.

Sambandet mellan medelkullens storlek (Y-axeln) och populationstätheten (X-axeln) uttryckt som procent av antalet holkar hos svartvita flugsnappare vid Lövsätter. bird ringing at Falsterbo Bird Observatory are another indication of a population decrease. These show a negative trend for the Pied Flycatcher over the period 1980-2011 $\left(\mathrm{r}_{\mathrm{s}}=-0.447, \mathrm{P}<0.01\right)$ (Table 3 ). The Swedish Pied Flycatcher population thus seems to have been decreasing for decades but the reason for this is uncertain. One possibility is that forests have become denser and thereby less attractive to flycatchers. This may be true in southern Sweden but is less likely in the north. Another possibility is that the flycatchers' wintering grounds or migratory stop-over sites have deteriorated.

In a nestbox population in England, a strong decrease took place recently, from 80 pairs in 1990 to 23 pairs in 2004, corresponding to a decrease by 4.2 pairs per year (Goodenough et al. 2009), but data from the preceding period showed a strong increase (A.E. Goodenough in litt.). In a longterm (1957-1989) German study (Winkel 1989, 1993), no trend was detected. Likewise, no statistically significant trend was found for the Pied Flycatcher in German capture data from 1972 to 1996 (Berthold et al. 1998). Pied Flycatchers also colonized northern Belgium (Dhondt et al. 1987), so the pattern of population changes is complicated.

With respect to causes of short-term fluctuations, Virolainen (1984) and Goodenough et al. (2009) found a significant correlation between mean number of fledglings in each year (year $t$ ) and the percent change in population size to the following year $(t+1)$. A reasonable assumption behind this is that the mean number of fledglings reflects the general environmental conditions during the breeding season. If these conditions are similar over larger areas, as could be expected for temperature and precipitation, one would also expect a correlation 
Table 2. Pine Marten* predation on Pied Flycatcher broods during 1983 through 2011 at Lövsätter. The table gives the number of nests suffering total loss and partial loss in each year.

Mårdpredationens* fördelning på totalförluster och partiella förluster hos svartvit flugsnappare vid Lövsätter åren 1983-2011.

\begin{tabular}{lcc}
\hline $\begin{array}{l}\text { Year } \\
\text { Ar }\end{array}$ & $\begin{array}{c}\text { Total losses } \\
\text { Totalförluster }\end{array}$ & $\begin{array}{c}\text { Partial losses } \\
\text { Delförluster }\end{array}$ \\
\hline 1983 & 5 & 0 \\
1984 & 0 & 0 \\
1985 & 5 & 0 \\
1986 & 6 & 1 \\
1987 & 4 & 1 \\
1988 & 0 & 0 \\
1989 & 0 & 0 \\
1990 & 0 & 1 \\
1991 & 3 & 0 \\
1992 & 0 & 0 \\
1993 & 12 & 1 \\
1994 & 2 & 0 \\
1995 & 5 & 4 \\
1996 & 0 & 0 \\
1997 & 3 & 1 \\
1998 & 0 & 0 \\
1999 & 0 & 0 \\
2000 & 0 & 0 \\
2001 & 0 & 0 \\
2002 & 0 & 0 \\
2003 & 0 & 0 \\
2004 & 0 & 0 \\
2005 & 0 & 0 \\
2006 & 3 & 0 \\
2007 & 6 & 0 \\
2008 & 1 & 1 \\
2009 & 0 & 0 \\
2010 & 0 & 2 \\
2010 & 0 & 0 \\
2011 & 0 & 0 \\
\hline \multirow{2}{*}{ P } & 0 & 0 \\
\hline
\end{tabular}

* Pine Marten predation is easy to identify because of nest material hanging out of the entrance hole.

* Mårdpredation identifieras lätt på att bomaterial hänger ut ur ingångshålet. between mean numbers of fledglings and capture indices at bird observatories. Such a correlation was found between mean number of fledglings in our study and autumn numbers of juvenile flycatchers captured at Falsterbo ( $\mathrm{rs}=0.401, \mathrm{P}<0.05$ ).

In Artemyev's (2008) study, the factor explaining the largest proportion of the variance in population fluctuation was the proportion of young (2Y) immigrants, which in turn correlated with ambient temperatures during the flycatchers' spring arrival period. Artemyev speculates that spring temperature may influence both mortality and breeding rates of second-year birds.

\section{Laying date}

A negative relationship between flycatcher laying date and ambient temperature, as found in the present study, has also been found in many other studies. Thus, in a study comprising Pied Flycatcher populations from most parts of Europe, this relationship was statistically significant for 20 out of 23 populations (Both et al. 2004). Considering that meteorological conditions, such as temperature, may vary in parallel over fairly large areas, it comes as no surprise that laying dates in those years that were common in the studies of Borgström (1990, 2001), Nilsson (2008) and the present one were strongly correlated in each case $(\mathrm{r}=0.66-0.86, \mathrm{P}<$ 0.001 ; the distances between the three study areas are between 130 and $380 \mathrm{~km}$ ).

In Pied Flycatchers, a gradually earlier breeding during the period 1970-1995 was found by Winkel \& Hudde (1997), and the Europe-wide study of Both et al. (2004) documented successively earlier laying dates during the 1980s and 1990s in most but not all of the flycatcher populations studied. Thus, only one of the four Swedish populations included in their study showed a (non-significant) trend towards earlier laying and none of them showed an

Table 3. Comparisons of population declines of Pied Flycatchers in some Swedish long-term studies. The slopes for corresponding years in the present study are given, as are the correlation coefficients.

Jämförelse av negative trender i svenska studier av svartvit flugsnappare. Tabellen ger regressionskoefficienten för de fyra lokalerna och för motsvarande år i denna studie. Dessutom ges korrelationskoefficienten ( $r$ ).

\begin{tabular}{|c|c|c|c|c|c|}
\hline $\begin{array}{l}\text { Year } \\
\text { Ar }\end{array}$ & $\begin{array}{l}\text { Locality } \\
\text { Lokal }\end{array}$ & $\begin{array}{l}\text { Slope } \\
\text { Lutning }\end{array}$ & $\begin{array}{l}\text { This study } \\
\text { Denna studie }\end{array}$ & $\begin{array}{l}\text { Correlation } \\
\text { Korrelation }\end{array}$ & $\begin{array}{l}\text { Refernce } \\
\text { Reference }\end{array}$ \\
\hline$\overline{1965-2010}$ & Ammarnäs & $-0.852 \%$ & $-0.694 \%$ & $r=0671$ & E. Nyholm in litt. \\
\hline 1978-2006 & Jämtland & $-0.900 \%$ & $-0.858 \%$ & $\mathrm{r}=0.667$ & Sjöberg (2006) \\
\hline 1980-2011 & Falsterbo & -3.894 inds & $-0.754 \%$ & $\mathrm{r}=0.413$ & Falsterbo Bird Observatory in litt. \\
\hline 1980-2010 & Sweden & $-1.400 \%$ & $-0.758 \%$ & $\mathrm{r}=0.777$ & S. Svensson in litt. \\
\hline
\end{tabular}


increase in temperature. The results of the present study as well as those of Borgström $(1990,2001)$ and Nilsson (2008) agree with this finding: neither May temperature nor laying date showed any statistically significant trend across years.

\section{Clutch size}

The mean clutch size observed in this study, 6.34 eggs, is very similar to clutch sizes found in other studies with similar laying dates (e.g. Hildén \& Haartman 1987, Borgström 1990, 2001, Lundberg \& Alatalo 1992, Nilsson 2008). It showed a weak negative relationship to population density (percent occupied boxes). A similar weak influence of population density on clutch size was found by Virolainen (1984). Clutch size decreases with the progress of the season (see below), but Virolainen's result remained after he removed the effect of laying date. Since one-year old females lay somewhat smaller clutches than older ones even after correction for laying date (Alatalo \& Lundberg 1992), a larger proportion of one-year old females in high-density years could contribute to the observed density effect.

In accordance with other studies where both clutch sizes and laying dates have been reported (for references, see Winkel 1993), clutch size decreased with the progress of the season, the so called "calendar effect" (von Haartman 1966). The decrease in the present study was 0.07 eggs per day later that clutches were started. This falls within the range normally reported (0.06-0.09; Winkel 1993), but lower values have also been documented (e.g. 0.05; Virolainen 1984, and 0.053 for 13 combined areas in Finland; Hildén \& Haartman 1987). However, the laying pattern in our study varied much between years and during the second half of the study, a high proportion of 7-egg clutches was laid after the median laying date. The 'calendar effect' may be an adaptation to a seasonally deteriorating food supply as demonstrated experimentally by Siikamäki (1998), who showed that when supplied with extra food, delayed broods survived better than similarly delayed broods without food supplementation.

\section{Breeding success}

Including total losses, a mean of 5.34 young fledged, corresponding to $84 \%$ of eggs laid, which according to Järvinen (1983) is well above the production necessary to make the population self-sustained (4.4 fledglings per breeding attempt). In only nine of the 62 years of the study was this number not attained and in each case this was mainly the result of predation. Nest predation is often local, but following the strong reduction of Red Fox Vulpes vulpes numbers because of sarcoptic mange which spread in Sweden in the 1980s (Lindström et al. 1995), there was a general increase of Pine Martens, which may have impacted on hole-nesting (as well as other) birds over large areas. It is, however, unlikely that nest predation by Pine Martens can explain the negative trend seen in several Swedish Pied Flycatcher populations both because the decrease started before the Pine Marten population increased and because the decrease has continued after Red Fox populations recovered.

\section{Acknowledgements}

We thank Lennart Karlsson at Falsterbo Bird Observatory for kindly putting data from the standardized ringing scheme at our disposal. Erik Nyholm and Tomas Pärt kindly provided constructive comments on an earlier version of the manuscript.

\section{References}

Artemyev, A. V. 2008. Factors responsible for the long-term dynamics of the Pied Flycatcher Ficedula hypoleuca populations in the taiga of Karelia, Russia. Acta Ornithol. 43: 10-16.

Booth, C. \& 22 other authors 2002. Large-scale geographical variation confirms that climate change causes birds to lay earlier. Proc. R. Soc. Lond. B 271: 1657-1662.

Berthold, B., Fiedler, W., Schlenker, R. \& Querner, O. 1998. A 25-year study of the population development of Central European songbirds: A general decline, most evident in long-distance migrants. Naturwissenschaften 85: 350 353.

Borgström, E. 1990. Breeding data for the Pied Flycatcher, Ficedula hypoleuca, in Central Sweden. Vår Fågelvärld 49: 140-146. (In Swedish with summary in English.)

Borgström, E. 2001. Häckningsbiologiska iakttagelser och aspekter på ungfåglars flyttning och honors ortstrohet hos svartvit flugsnappare Ficedula hypoleuca i mellersta Värmland. Värmlandsornitologen 29: 65-73. (In Swedish.)

Dhondt, A. A., Fierens, F., Lambrechts, M., Adriaensen, F., Matthysen, E. , De Laet, J. \& Bijnens, L. 1987. The establishment of a breeding population of the Pied Flycatcher, Ficedula hypoleuca, in the Peerdsbos, near Antwerp. Gerfaut 77: 333-339.

Goodenough, A. E., Elliot, S. L. \& Hart, A. G. 2009. The challenges of conservation for declining migrants: are reserve-based initiatives during the breeding season appropriate for the Pied Flycatcher Ficedula hypoleuca? Ibis 151: 429-439.

von Haartman, L. 1966. Clutch-size in the Pied Flycatcher. Proc. 24 Int. Ornithol. Congr. 155-164. 
von Haartman, L. 1989. Breeding time of the Pied Flycatcher Ficedula hypoleuca. Pp. 1-16 in Population Biology of Passerine Birds. An Integrated Approach (Blondel, J., Gosler, A., Lebreton, J.-D. \& McCleery, R.. eds). NATO ASI Series, Series G: Ecological Sciences Vol. 24. Springer-Verlag Berlin, Heidelberg.

Hildén, O. \& von Haartmann, L. 1987. A decade of population studies in box-nesting small passerines in Finland. Lintumies 22: 70-75. (In Finnish with summary in English.)

Järvinen, A. 1983. Breeding strategies of hole-nesting passerines in northern Lapland. Ann. Zool. Fennici 20: 129149.

Järvinen, A. \& Väisänen, R. A. 1984. Reproduction of Pied Flycatchers (Ficedula hypoleuca) in good and bad breeding seasons in a northern marginal area. Auk 101: 439-450.

Lindström, E. R., Brainerd, S. M., Helldin, J. O. \& Overskaug, K. 1995. Pine marten - red fox interactions: a case of intraguild predation? Ann. Zool. Fennici 32: 123-130.

Lundberg, A. \& Alatalo, R. V. 1992. The Pied Flycatcher. T \& AD Poyser, London.

Nilsson, J.-E. 2008. A 20-year study of a nest-box breeding bird population with special regard to the Pied Flycatcher Ficedula hypoleuca. Ornis Svecica 18: 52-64.

Ottvall, R., Edenius, L., Elmberg, J., Engström, H., Green, M., Holmqvist, N., Lindström, A. \& Tjernberg, M. 2009. Population trends for Swedish breeding birds. Ornis Svecica 19: 117-192.

Schölin, K.-G. 2009. A long-term study of the breeding biology of the Great Tit Parus major in a mixed forest in South Central Sweden. Ornis Svecica 19: 222-232. (In Swedish with summary in English.)

Siikamäki, P. 1998. Limitation of reproductive success by food availability and breeding time in Pied Flycatchers. Ecology 79: 1789-1796.

Sjöberg, N. 2006. Arrival dates 1948-2006 and breeding 1978-2006 in Jämtland for Pied Flycatcher Ficedula hypoleuca, Redstart Phoenicurus phoenicurus and Willow Warbler Phylloscopus trochilus. Ornis Svecica 16: 118126. (In Swedish with summary in English.)

Virolainen, M. 1984. Breeding biology of the Pied Flycatcher Ficedula hypoleuca in relation to population density. Ann. Zool. Fennici 21: 187-197.

Winkel, W. 1989. Langfristige Bestandsentwicklung von Kohlmeise (Parus major) und Trauerschnäpper (Ficedula hypoleuca). Ergebnisse aus Niedersachsen. J. Ornithol. 123: 335-343.

Winkel, W. 1993. Ficedula hypoleuca (Pallas 1764) - Trauerfliegenschnäpper, Trauerschnäpper. Pp. 165-263 in Handbuch der Vögel Mitteleuropas (Glutz von Blotzheim, U. N. ed.), Bd 13/I, Aula-Verlag, Wiesbaden.

Winkel, W. \& Hudde, H. 1997. Long-term trends in reproductive traits of tits (Parus major, P. caruleus) and Pied Flycatchers Ficedula hypoleuca. J. Avian Biol. 28: 187190.

\section{Sammanfattning}

Eftersom den svartvita flugsnapparen gärna häckar i holkar finns en omfattande litteratur om arten, särskilt dess häckningsbiologi (se Lundberg \& Alatalo
1992). Denna uppsats redovisar resultaten från en långtidsstudie, som initierades 1948 och som fortfarande pågår. Dess viktigaste resultat är nog den negativa betåndsutveckling som fortgått alltsedan studiens start.

\section{Metod}

Inför häckningssäsongen 1948 satte uppsatsens försteförfattare upp 80 holkar i ett skogsområde sydost om Örebro och han har också stått för allt fältarbete sedan dess. Området har beskrivits i Schölin (2009) och består huvudsakligen av blandskog omväxlande med små, numera delvis övergivna och igenväxande åkerlyckor. Holkarna placerades på c. 2,5 m höjd med 40-50 meters mellanrum längs en vindlande rutt inom en yta av ungefär $0,5 \times 1$ $\mathrm{km}$. Flertalet holkar var gjorda av brädor, medan ungefär en tredjedel bestod av urholkade trädstammar. De hade en genomsnittlig bottenyta av 112 $\mathrm{cm}^{2}$ och ingångshål med $30 \mathrm{~mm}$ diameter placerat c. $16 \mathrm{~cm}$ från holkens botten. De kontrollerades i allmänhet en gång i veckan (ibland litet glesare) för att bestämma häckningsstart, kullstorlek, ungöverlevnad, osv. Kullar för vilka läggningsstarten inte blev tillfredställande bestämd har uteslutits från beräkning av läggstart medan 16 kullar, som startats i slutet av juni eller senare, uteslutits helt och hållet (se von Haartman 1989). Temperaturdata för maj har tagits from SMHI:s station i Örebro. Statistiska analyser har utförts med sedvanliga metoder, och i linjära regressioner, där datum utgör den oberoende variabeln är $1 \mathrm{maj}=1$, och $\mathrm{i}$ fall där denna variabel är år, är $1949=1$. Regressioner med procent har arcsin-kvadratrot-transformerats, men otransformerade värden anges i texten. Medeltal presenteras \pm standardavvikelsen (SD).

\section{Resultat}

Vid studiens start 1949 var c. $50 \%$ av holkarna bebodda av svartvita flugsnappare. Denna andel hade år 2011 fallit till knappa 20\%, en årlig minskning som svarar mot ett halvt par per år (Figur 1). Minskningen är höggradigt statistiskt signifikant ( $\mathrm{P}$ $<0,001)$.

Det fanns ett starkt negativt samband mellan antalet flugsnappare och antalet övriga holkhäckare, främst talgoxe Parus major och blåmes Cyanistes caeruleus (Figur 2, $\mathrm{r}_{\mathrm{s}}=-0.808, \mathrm{P}<0,001$ ), dvs många övriga hålhäckare betydde färre flugsnappare, men det fanns varje år ett antal tomma holkar. Det är osäkert om det föreligger ett orsakssamband mellan mesarnas ökning och flugsnapparnas 
minskning. Vi fann ett relativt svagt (men signifikant) samband mellan medelproduktionen av flygga ungar ett år och beståndsstorleken följande häckningssäsong.

Medeldatum för läggstarten varierade under studieperioden från 17 maj det tidigaste året (1994) till 3 juni det senaste (1991), med 24 maj som medeltal för alla år sammantagna ( $N=61$ år). Läggstarten var negativt relaterad till medeltemperaturen i maj, dvs ju högre majtemperatur desto tidigare start. Det tidigast lagda ägget (Tabell 1) under något år lades den 10 maj (1993 och 1994). Vare sig majtemperatur eller läggstart visade någon statistiskt signifikant trend över de sex decennierna (Figur 3, Figur 4).

Kullstorleken för samtliga år 1948-2011 var 6,34, med 6-kullar som de mest frekventa. Den lägsta genomsnittliga kullstorleken $(5,76)$ registrerades 1991, den högsta $(7,08) 2011$ (Appendix 1). Under studiens första hälft låg medelkullstorleken relativt stabilt kring 6,24 ägg (variationskoefficienten, $\mathrm{CV}=2,2 \%$ ), medan den under den andra hälften varierade avsevärt mer mellan åren $(\mathrm{CV}=$ $4,5 \%$ ) (Figur 5), troligen en effekt av mer variabla läggdatum under den senare perioden (jfr Figur 3) och en lägre populationstäthet (Figur 6). Medelkullen de olika åren minskade med 0,07 ägg/dag när materialet standardiserats efter medianläggdatum.

Medelantalet flygga ungar per kull beräknat på 1397 påbörjade kullar var 5,34 och för 1264 kullar i vilka minst en unge kom på vingarna, 5,96 (Appendix 2). Om alla kullar med totalförluster utesluts, så resulterade mellan 78 och 100 procent av lagda ägg i flygga ungar (medeltal 93\%). Totalförluster var emellertid ganska vanliga. Av de 1397 påbörjade kullarna misslyckades $133(9,5 \%)$ helt. Särskilt efter 1983 var förlusterna huvudsakligen orsakade av mårdpredation (Tabell 2), som förekom under 15 av de 29 åren. Andra totalförluster orsakades av större hackspett Dendrocopos major (15 kullar), övergivningar (12 kullar) och ungdöd (40 kullar, vanligen kort tid efter kläckning). I ytterligare 12 fall var bona tomma men intakta.

\section{Diskussion}

Under de senaste åren har negativa populationstrender för svartvit flugsnappare noterats $\mathrm{i}$ en del svenska studier (Sjöberg 2006, E. Nyholm i brev, Ottvall m.fl. 2009). I två lövskogsdungar, där en av författarna till denna uppsats (HK) på 1970-talet i sina holkar hade i medeltal 30 respektive 19 par flugsnappare, har i ett nytt holkprojekt under åren 2004-2010 inte ett enda par häckat (D. Hasselquist i brev). En ytterligare indikation på en negativ beståndsutveckling kommer från Falsterbo fågelstations standardiserade ringmärkningar, vilka visar en statistiskt signifikant negativ trend för svartvit flugsnappare under perioden 1980-2011 (Tabell 3). Vår studie visar att beståndsminskningen kan ha pågått betydligt längre, men beklagligtvis tycks dataserier av motsvarande längd saknas som jämförelse.

Som också iakttagits i flera andra undersökningar (se t.ex. Both m.fl. 2004), varierade medeldatum för värpstarten de olika åren med maj månads medeltemperatur. Eftersom väderförhållanden ofta är relativt likartade åtminstone över måttligt stora områden, är det föga förvånande att läggdatum var starkt korrelerade mellan Råda i Värmland (Borgström 1990, 2001), trakten mellan Tranås och Gränna (Nilsson 2008) och Örebro-trakten (denna studie). Avstånden mellan de tre lokalerna är 130 $380 \mathrm{~km}$.

I en studie av Both m.fl. (2004), baserad på flugsnappardata från praktiskt taget hela Europa, fann man i flertalet fall att läggstarten under 1980- och 1990-talen inträffat allt tidigare liksom att temperaturen stigit under samma period. Undantag utgjorde några av de ingående svenska lokalerna, där varken majtemperaturen eller läggstarten förändrats under de två decennierna. Vår studie, liksom de nämnda studierna av Borgström och Nilsson, passar in i detta mönster; varken majtemperatur eller läggdatum uppvisar någon trend under de år respektive studie pågått.

Den genomsnittliga kullstorleken, 6,34 ägg, ligger inom samma ganska snäva intervall som konstaterats inom områden med likartade läggdatum (Haartman \& Hildén 1987, Borgström 1990, 2001, Lundberg \& Alatalo 1992, Nilsson 2008). Den visade ett svagt negativt samband med antalet häckande par, något som också Virolainen (1984) fann. Hos den svartvita flugsnapparen minskar kullstorleken med säsongens framskridande, den s.k. kalendereffekten (Haartman 1966). Minskningen i denna studie var 0,07 ägg per dag, vilket ligger inom ramen för de oftast rapporterade värdena (Winkel 1993).

Med totalförluster inkluderade, blev i medeltal 5,34 ungar flygga, eller $84 \%$ av lagda ägg. Enligt Järvinen (1983) krävs 4,4 flygga ungar för att beståndet skall upprätthållas utan inflyttning. Under blott nio av de 61 åren nåddes inte denna nivå, nästan uteslutande beroende på predation, framför allt av mård (Tabell 1). Den iakttagna beståndsminskningen kan därför knappast tillskrivas ett dåligt häckningsresultat. 
Appendix 1. Yearly clutch size distributions and mean clutch sizes of Pied Flycatchers at Lövsätter, South Central Sweden during 1948-2010. No complete clutches with less than 4 eggs.

Kullstorleksfördelning och medelkullstorlekar för svartvita flugsnappare vid Lövsätter sydost om Örebro under åren 1948-2010. Inga fulla kullar med färre än 4 ägg.

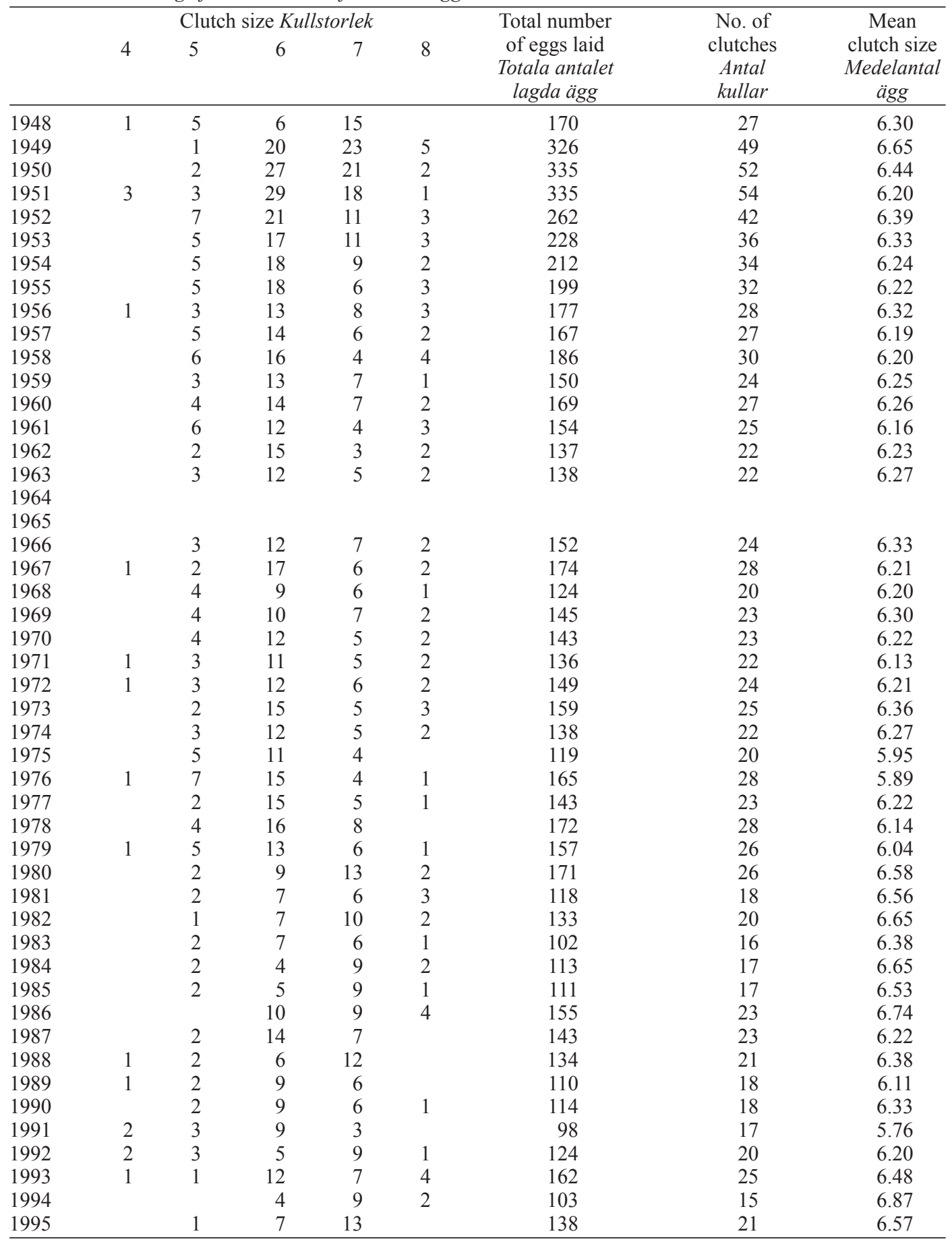


Appendix 1 forts.

\begin{tabular}{|c|c|c|c|c|c|c|c|c|}
\hline & \multicolumn{5}{|c|}{ Clutch size Kullstorlek } & \multirow{2}{*}{$\begin{array}{l}\text { Total number } \\
\text { of eggs laid } \\
\text { Totala antalet } \\
\text { lagda ägg }\end{array}$} & \multirow{2}{*}{$\begin{array}{c}\text { No. of } \\
\text { clutches } \\
\text { Antal } \\
\text { kullar }\end{array}$} & \multirow{2}{*}{$\begin{array}{c}\text { Mean } \\
\text { clutch size } \\
\text { Medelantal } \\
\text { ägg }\end{array}$} \\
\hline & 4 & 5 & 6 & 7 & 8 & & & \\
\hline 1977 & & 2 & 15 & 5 & 1 & 143 & 23 & 6.22 \\
\hline 1978 & & 4 & 16 & 8 & & 172 & 28 & 6.14 \\
\hline 1979 & 1 & 5 & 13 & 6 & 1 & 157 & 26 & 6.04 \\
\hline 1980 & & 2 & 9 & 13 & 2 & 171 & 26 & 6.58 \\
\hline 1981 & & 2 & 7 & 6 & 3 & 118 & 18 & 6.56 \\
\hline 1982 & & 1 & 7 & 10 & 2 & 133 & 20 & 6.65 \\
\hline 1983 & & 2 & 7 & 6 & 1 & 102 & 16 & 6.38 \\
\hline 1984 & & 2 & 4 & 9 & 2 & 113 & 17 & 6.65 \\
\hline 1985 & & 2 & 5 & 9 & 1 & 111 & 17 & 6.53 \\
\hline 1986 & & & 10 & 9 & 4 & 155 & 23 & 6.74 \\
\hline 1987 & & 2 & 14 & 7 & & 143 & 23 & 6.22 \\
\hline 1988 & 1 & 2 & 6 & 12 & & 134 & 21 & 6.38 \\
\hline 1989 & 1 & 2 & 9 & 6 & & 110 & 18 & 6.11 \\
\hline 1990 & & 2 & 9 & 6 & 1 & 114 & 18 & 6.33 \\
\hline 1991 & 2 & 3 & 9 & 3 & & 98 & 17 & 5.76 \\
\hline 1992 & 2 & 3 & 5 & 9 & 1 & 124 & 20 & 6.20 \\
\hline 1993 & 1 & 1 & 12 & 7 & 4 & 162 & 25 & 6.48 \\
\hline 1994 & & & 4 & 9 & 2 & 103 & 15 & 6.87 \\
\hline 1995 & & 1 & 7 & 13 & & 138 & 21 & 6.57 \\
\hline 1996 & & 1 & 8 & 8 & & 109 & 17 & 6.41 \\
\hline 1997 & & 1 & 5 & 5 & & 70 & 11 & 6.36 \\
\hline 1998 & & 1 & 4 & 5 & & 64 & 10 & 6.40 \\
\hline 1999 & 2 & & 4 & 4 & & 60 & 10 & 6.00 \\
\hline 2000 & & 1 & 5 & 3 & 2 & 72 & 11 & 6.55 \\
\hline 2001 & & 2 & 6 & 4 & 1 & 82 & 13 & 6.31 \\
\hline 2002 & 1 & 2 & 5 & 2 & 1 & 66 & 11 & 6.00 \\
\hline 2003 & 1 & & 7 & 4 & & 74 & 12 & 6.17 \\
\hline 2004 & & & 4 & 10 & 2 & 110 & 16 & 6.88 \\
\hline 2005 & & & 5 & 15 & 2 & 151 & 22 & 6.86 \\
\hline 2006 & 1 & 2 & 7 & 9 & & 119 & 19 & 6.26 \\
\hline 2007 & & & 8 & 5 & 2 & 99 & 15 & 6.60 \\
\hline 2008 & & 1 & 4 & 9 & 1 & 100 & 15 & 6.67 \\
\hline 2009 & & & 2 & 5 & 2 & 63 & 9 & 7.00 \\
\hline 2010 & & 1 & 3 & 6 & 2 & 81 & 12 & 6.75 \\
\hline 2011 & & & 2 & 7 & 3 & 85 & 12 & 7.08 \\
\hline Total & 22 & 155 & 648 & 472 & 100 & 8855 & 1397 & 6.34 \\
\hline$\%$ & 1.6 & 11.1 & 46.4 & 33.8 & 7.2 & & & \\
\hline
\end{tabular}


Appendix 2. Number of Pied Flycatcher broods at Lövsätter, South Central Sweden from which 0, 1, 2, 3, etc. young fledged in each year and mean number of fledged young per brood for all broods (1) and for broods that produced at least one fledgling (2).

Antal kullar från vilka 0, 1, 2, 3, etc. ungar blev flygga respektive år samt medeltal flygga för samtliga kullar (1) och från kullar där minst en unge blev flygg vid Lövsätter sydost om Örebro 1948-2010.

\begin{tabular}{|c|c|c|c|c|c|c|c|c|c|c|c|c|c|c|}
\hline & \multicolumn{9}{|c|}{ No. of young fledged Antal flygga ungar } & \multirow{2}{*}{$\begin{array}{c}\text { Total } \\
\text { fledged } \\
\text { Flygga } \\
\text { totalt }\end{array}$} & \multirow{2}{*}{$\begin{array}{l}\text { No. of } \\
\text { broods } \\
(1) \\
\text { Antal } \\
\text { kullar } \\
(1) \\
\end{array}$} & \multirow{2}{*}{$\begin{array}{c}\text { Mean per } \\
\text { brood } \\
(1) \\
\text { Medeltal } \\
\text { per kull } \\
(1)\end{array}$} & \multirow{2}{*}{$\begin{array}{l}\text { No. of } \\
\text { broods } \\
(2) \\
\text { Antal } \\
\text { kullar } \\
(2)\end{array}$} & \multirow{2}{*}{$\begin{array}{l}\text { Mean per } \\
\text { brood } \\
(2) \\
\text { Medeltal } \\
\text { per kull } \\
(2)\end{array}$} \\
\hline & 0 & 1 & 2 & 3 & 4 & 5 & 6 & 7 & 8 & & & & & \\
\hline 1948 & 3 & & & & 2 & 6 & 7 & 9 & & 143 & 27 & 5.30 & 24 & 5.96 \\
\hline 1949 & 3 & & 1 & 1 & 1 & 4 & 20 & 17 & 2 & 284 & 49 & 5.80 & 46 & 6.17 \\
\hline 1950 & 3 & & 1 & 1 & 5 & 7 & 21 & 13 & 1 & 285 & 52 & 5.48 & 49 & 5.82 \\
\hline 1951 & & & 1 & & 5 & 7 & 26 & 14 & 1 & 319 & 54 & 5.91 & 54 & 5.91 \\
\hline 1952 & 2 & & & 1 & & 13 & 15 & 8 & 3 & 238 & 42 & 5.67 & 40 & 5.95 \\
\hline 1953 & 3 & & & 1 & 1 & 7 & 15 & 7 & 2 & 197 & 36 & 5.47 & 33 & 5.97 \\
\hline 1954 & 3 & & & & 1 & 6 & 17 & 5 & 2 & 187 & 34 & 5.50 & 31 & 6.03 \\
\hline 1955 & 1 & & 1 & & 2 & 8 & 13 & 5 & 2 & 179 & 32 & 5.59 & 31 & 5.77 \\
\hline 1956 & 1 & & 1 & & 3 & 4 & 11 & 6 & 2 & 158 & 28 & 5.64 & 27 & 5.85 \\
\hline 1957 & 1 & & & & 1 & 8 & 11 & 5 & 1 & 153 & 27 & 5.67 & 26 & 5.88 \\
\hline 1958 & 4 & & & & 1 & 5 & 12 & 5 & 3 & 160 & 30 & 5.33 & 26 & 6.15 \\
\hline 1959 & 2 & & & & & 3 & 11 & 7 & 1 & 138 & 24 & 5.75 & 22 & 6.27 \\
\hline 1960 & 4 & 1 & & & 1 & 3 & 13 & 4 & 1 & 134 & 27 & 4.96 & 23 & 5.83 \\
\hline 1961 & 1 & & & & & 8 & 11 & 3 & 2 & 143 & 25 & 5.72 & 24 & 5.96 \\
\hline 1962 & & & & & & 6 & 11 & 4 & 1 & 132 & 22 & 6.00 & 22 & 6.00 \\
\hline 1963 & & & & & & 6 & 9 & 5 & 2 & 135 & 22 & 6.14 & 22 & 6.14 \\
\hline 1964 & & & & & & & & & & & & & & \\
\hline 1965 & & & & & & & & & & & & & & \\
\hline 1966 & & & & & 1 & 4 & 12 & 6 & 1 & 146 & 24 & 6.08 & 24 & 6.08 \\
\hline 1967 & 2 & & & & 2 & 3 & 14 & 5 & 2 & 158 & 28 & 5.64 & 26 & 6.08 \\
\hline 1968 & 1 & & & & & 5 & 7 & 6 & 1 & 117 & 20 & 5.85 & 19 & 6.16 \\
\hline 1969 & & & & & & 6 & 11 & 4 & 2 & 140 & 23 & 6.09 & 23 & 6.09 \\
\hline 1970 & 1 & & & & 1 & 6 & 10 & 3 & 2 & 131 & 23 & 5.70 & 22 & 5.95 \\
\hline 1971 & 1 & & & & 1 & 6 & 8 & 5 & 1 & 125 & 22 & 5.68 & 21 & 5.95 \\
\hline 1972 & 2 & & & & & 6 & 10 & 5 & 1 & 133 & 24 & 5.54 & 22 & 6.05 \\
\hline 1973 & & & & & & 5 & 16 & 3 & 1 & 150 & 25 & 6.00 & 25 & 6.00 \\
\hline 1974 & 1 & & & & & 7 & 9 & 4 & 1 & 125 & 22 & 5.68 & 21 & 5.95 \\
\hline 1975 & 1 & & & & 1 & 7 & 10 & 1 & & 106 & 20 & 5.30 & 19 & 5.58 \\
\hline 1976 & 2 & & & 1 & 3 & 10 & 9 & 3 & & 140 & 28 & 5.00 & 26 & 5.38 \\
\hline 1977 & 4 & & & & & 4 & 12 & 3 & & 113 & 23 & 4.91 & 19 & 5.95 \\
\hline 1978 & 2 & & 1 & & & 10 & 13 & 2 & & 144 & 28 & 5.14 & 26 & 5.54 \\
\hline 1979 & 2 & & & & 1 & 9 & 11 & 3 & & 136 & 26 & 5.23 & 24 & 5.67 \\
\hline 1980 & & & 1 & & 1 & 3 & 12 & 9 & & 156 & 26 & 6.00 & 26 & 6.00 \\
\hline 1981 & & & & & & 3 & 6 & 8 & 1 & 115 & 18 & 6.39 & 18 & 6.39 \\
\hline 1982 & & & & & & 3 & 8 & 8 & 1 & 127 & 20 & 6.35 & 20 & 6.35 \\
\hline 1983 & 6 & & & & 1 & 3 & & 6 & & 61 & 16 & 3.81 & 10 & 6.10 \\
\hline 1984 & 1 & & & & & 2 & 6 & 7 & 1 & 103 & 17 & 6.06 & 16 & 6.44 \\
\hline 1985 & 4 & & & & & 2 & 3 & 8 & & 84 & 17 & 4.94 & 13 & 6.46 \\
\hline 1986 & 6 & & 1 & & & 1 & 5 & 9 & 1 & 108 & 23 & 4.70 & 17 & 6.35 \\
\hline 1987 & 6 & 1 & 1 & & & 3 & 10 & 2 & & 92 & 23 & 4.00 & 17 & 5.41 \\
\hline 1988 & & & & & 1 & 3 & 7 & 10 & & 131 & 21 & 6.24 & 21 & 6.24 \\
\hline 1989 & 1 & 1 & & & 2 & 1 & 9 & 4 & & 96 & 18 & 5.33 & 17 & 5.65 \\
\hline 1990 & 1 & & 1 & 2 & 1 & 4 & 5 & 3 & 1 & 91 & 18 & 5.06 & 17 & 5.35 \\
\hline 1991 & 4 & & 1 & & 2 & 3 & 6 & 1 & & 68 & 17 & 4.00 & 13 & 5.23 \\
\hline 1992 & & & & & 3 & 5 & 7 & 4 & 1 & 115 & 20 & 5.75 & 20 & 5.75 \\
\hline
\end{tabular}


Appendix 2. forts

\begin{tabular}{|c|c|c|c|c|c|c|c|c|c|c|c|c|c|c|}
\hline & \multicolumn{9}{|c|}{ No. of young fledged Antal flygga ungar } & \multirow{2}{*}{$\begin{array}{c}\begin{array}{c}\text { Total } \\
\text { fledged }\end{array} \\
\text { Flygga } \\
\text { totalt }\end{array}$} & \multirow{2}{*}{$\begin{array}{l}\text { No. of } \\
\text { broods } \\
(1) \\
\text { Antal } \\
\text { kullar } \\
(1)\end{array}$} & \multirow{2}{*}{$\begin{array}{l}\text { Mean per } \\
\text { brood } \\
(1) \\
\text { Medeltal } \\
\text { per kull } \\
(1)\end{array}$} & \multirow{2}{*}{$\begin{array}{l}\text { No. of } \\
\text { broods } \\
(2) \\
\text { Antal } \\
\text { kullar } \\
(2)\end{array}$} & \multirow{2}{*}{$\begin{array}{l}\text { Mean per } \\
\text { brood } \\
(2) \\
\text { Medeltal } \\
\text { per kull } \\
\text { (2) }\end{array}$} \\
\hline & 0 & 1 & 2 & 3 & 4 & 5 & 6 & 7 & 8 & & & & & \\
\hline 1993 & 14 & & 1 & & 2 & 3 & 4 & 1 & & 56 & 25 & 2.24 & 11 & 5.09 \\
\hline 1094 & 4 & & 1 & 1 & & 1 & 3 & 4 & 1 & 64 & 15 & 4.27 & 11 & 5.82 \\
\hline 1995 & 6 & 1 & 1 & 2 & 1 & 2 & 5 & 3 & & 74 & 21 & 3.52 & 15 & 4.93 \\
\hline 1996 & 3 & 1 & & 1 & 1 & 2 & 4 & 5 & & 77 & 17 & 4.53 & 14 & 5.50 \\
\hline 1997 & 4 & 1 & & & 2 & 1 & 2 & 1 & & 33 & 11 & 3.00 & 7 & 4.71 \\
\hline 1998 & 1 & & & & 1 & 1 & 3 & 4 & & 55 & 10 & 5.50 & 9 & 6.11 \\
\hline 1999 & 3 & & & & 1 & 2 & 2 & 2 & & 40 & 10 & 4.00 & 7 & 5.71 \\
\hline 2000 & & & & & & 1 & 6 & 4 & & 69 & 11 & 6.27 & 11 & 6.27 \\
\hline 2001 & & & & & 1 & 4 & 5 & 3 & & 75 & 13 & 5.77 & 13 & 5.77 \\
\hline 2002 & 1 & 1 & & & 2 & 1 & 5 & 1 & & 51 & 11 & 4.64 & 10 & 5.10 \\
\hline 2003 & 1 & & & & 3 & & 6 & 2 & & 62 & 12 & 5.17 & 11 & 5.64 \\
\hline 2004 & 2 & & 1 & & 1 & 4 & 2 & 4 & 2 & 82 & 16 & 5.13 & 14 & 5.86 \\
\hline 2005 & & & & & & 3 & 7 & 10 & 2 & 143 & 22 & 6.50 & 22 & 6.50 \\
\hline 2006 & 7 & 1 & 1 & & 1 & 1 & 5 & 3 & & 63 & 19 & 3.32 & 12 & 5.25 \\
\hline 2007 & 6 & & & 1 & 1 & 4 & 2 & & 1 & 47 & 15 & 3.13 & 9 & 5.22 \\
\hline 2008 & 1 & 1 & & & 2 & 1 & 5 & 5 & & 79 & 15 & 5.27 & 14 & 5.64 \\
\hline 2009 & 1 & & & & & 1 & 3 & 3 & 1 & 52 & 9 & 5.78 & 8 & 6.50 \\
\hline 2010 & & 1 & & & 1 & 1 & 5 & 3 & 1 & 69 & 12 & 5.83 & 12 & 5.75 \\
\hline 2011 & & & & & 2 & 1 & 5 & 3 & 1 & 72 & 12 & 6.00 & 12 & 6.00 \\
\hline Total & 133 & 10 & 16 & 12 & 66 & 259 & 538 & 310 & 53 & 7459 & 1397 & 5.34 & 1264 & 5.96 \\
\hline
\end{tabular}

